УДК 349.2:331.104:347.965-057.164

DOI https://doi.org/10.32849/2663-5313/2019.9.12

\title{
Олена Луценко,
}

канд. юрид.наук,

асистент кафедри трудового права

Начіонального юридичного університету

імені Ярослава Мудрого

\section{ВИНИКНЕННЯ ТРУДОВИХ ПРАВОВІДНОСИН 3 ПОМІЧНИКОМ АДВОКАТА}

Стаття присвячена проблемним питанням, які з'являються під час виникнення трудових правовідносин із помічником адвоката. Автор зачіпає важливі аспекти, які стосуються виникнення трудових правовідносин та отримання статусу помічника адвоката. Зокрема, автор ставить запитання та дає відповіді щодо моменту виникнення трудових правовідносин і моменту отримання статусу помічника адвоката. Автор з'ясовує, який із иих двох фактів матиме значення для отримання у майбутньому свідочтва на ведення адвокатської діяльності, з якого моменту починає обчислюватися стаж помічника адвоката.

Автор встановив, що суттєвою проблемою для реалізачії помічником адвоката своєї трудової функиї та отримання стажу роботи як помічника адвоката є те, що на практииі має місие така ситуачія: особа вже прийнята на роботу помічником адвоката, але оскільки посвідчення ия особа не має, то фактично не може виконувати доручення свого роботодавия. I тому цей строк (перебування у трудових правовідносинах, але без посвідчення помічника адвоката) не зараховується до стажу роботи, який надалі потрібен для отримання посвідчення адвоката.

Автор дійшов висновків, що процедура отримання статусу помічника адвоката занадто ускладнена, а тому потребує суттєвого спрощення та переформатування. Доводиться, що стаж помічника адвоката має рахуватися з моменту виникнення трудових правовідносин між адвокатом та його помічником, а датою отримання свідоитва про помічника адвоката має бути саме дата виникнення трудових правовідносин із ним, позаяк уже з цього моменту особа починає безпосереднє виконання своєї трудової функиії. Внесення даних до реєстру та виготовлення посвідчення помічника адвоката повинні стати лише формальним підтвердженням того, що певний адвокат має власного помічника. Рада адвокатів регіону має лише вносити відомості про помічника адвоката до реєстру, тобто діі Ради адвокатів мають бути зведені лише до формального, технічного аспекту. Аргументовано, що вимога про проходження курсу-інструктажу введення в професію помічника адвоката Вищої школи адвокатури НААУ для особи, яка має повну вищу юридичну освіту, порушує принцип доступу до професії, адже підтвердженням професійного рівня особи є диплом про повну вищу освіту, позаяк особа, яка має такий рівень підготовки, має необхідні знання для виконання тих завдань та доручень, які даватиме адвокат.

Ключові слова: помічник адвоката, трудові правовідносини, адвокатська діяльність, свідоцтво помічника адвоката, статус помічника адвоката, стаж помічника адвоката.

Постановка проблеми. Помічник адвоката приймається на роботу для допомоги адвокату в здійсненні його діяльності. Помічник адвоката надає допомогу технічного характеру, як-от: робить витяги з матеріалів адвокатського досьє, робить копії та витяги з документів, збирає документи та інші матеріали, необхідні адвокату для виконання прийнятих ним доручень тощо, а також виконує завдання правового характеру: веде за дорученням та під контролем адвоката нескладні судові справи та надає консультації з питань законодавства, у нескладних справах за дорученням адвоката знайомиться 3 матеріалами справи та ін. Як правило, помічники адвоката - це особи, які згодом бажають набути статусу адвоката, тому отримання досвіту роботи у сфері адвокатської діяльності є вкрай важливим, позаяк у такий спосіб вони знайомляться 3 особливостями цього виду діяльності, що допомагає надалі як у складанні кваліфікаційного іспиту, так і у майбутній правозастосовній діяльності. Проте, на жаль, нині отримання статусу помічника адвоката вкрай ускладнене безліччю формальних процедур.

Мета статті - проаналізувати процедуру отримання статусу помічника адвоката, виявити низку проблем на шляху до отримання цього статусу та запропонувати авторське бачення спрощення процедур. 
Аналіз останніх досліджень і публікацій. Питання виникнення трудових правовідносин із помічниками адвокатів малодосліджене. Лише в окремих статтях науковці зачіпали зазначену тематику, зокрема: Л. Ю. Величко, О. А. Яковлєв, І. О. Головань та ін.

Виклад основного матеріалу. Як справедливо стверджує О. А. Яковлєв, можна виокремити три види правовідносин в адвокатській діяльності, щодо яких потрібно вирішити, чи можуть бути ці правовідносини трудовими:

1) правовідносини, поміж адвокатом (адвокатським бюро, адвокатським об'єднанням) й іншими особами, які сприяють у виконанні адвокатом своїх функцій (помічники, обслуговуючий персонал тощо);

2) правовідносини поміж адвокатом і адвокатським бюро (адвокатським об'єднанням);

3) правовідносини поміж адвокатом і особою, якій адвокат надає послуги.

Перший вид відносин, на переконання науковця, може бути визначений як трудові правовідносини [1, с. 143].

Відповідно до ч. 1 ст. 16 Закону України «Про адвокатуру та адвокатську діяльність» [2] адвокат може мати помічників з числа осіб, які мають повну вищу юридичну освіту. Помічники адвоката працюють на підставі трудового договору (контракту), укладеного 3 адвокатом, адвокатським бюро, адвокатським об'єднанням, $з$ додержанням вимог цього Закону і законодавства про працю.

Згідно зі ст. 21 Кодексу законів про працю України [3] трудовий договір - це угода між працівником і власником підприємства, установи, організації або уповноваженим ним органом чи фізичною особою, за якою працівник зобов'язується виконувати роботу, визначену цією угодою, з підляганням внутрішньому трудовому розпорядкові, а власник підприємства, установи, організації або уповноважений ним орган чи фізична особа зобов'язується виплачувати працівникові заробітну плату і забезпечувати умови праці, необхідні для виконання роботи, передбачені законодавством про працю, колективним договором і угодою сторін.

У свою чергу, засади організації, правовий статус та умови діяльності особи, яка займає посаду помічника адвоката, умови і порядок використання адвокатами у здійсненні своєї професійної діяльності праці помічників визначає та регламентує Положення про помічника адвоката, затверджене рішенням Ради адвокатів України від 25 вересня 2015 р. № 113 (далі - Положення) [4].
Помічник адвоката - фізична особа, яка здійснює діяльність на підставі та в порядку, що передбачені Законом України «Про адвокатуру та адвокатську діяльність», Кодексом законів про працю України, Правилами адвокатської етики та Положенням про помічника адвоката. Помічником адвоката може бути фізична особа, яка: $є$ громадянином України або іноземним громадянином, чи особою без громадянства, які у встановленому порядку отримали дозвіл на працевлаштування в Україні на посаду помічника адвоката; має повну вищу юридичну освіту; володіє державною мовою; прослухала спеціальний курс-інструктаж введення в професію помічника адвоката у Вищій школі адвокатури НААУ [4]. Ці приписи визначені у розділі 2 Положення про помічника адвоката [4] «Набуття статусу помічника адвоката. Організаційні форми праці помічника адвоката», але, окрім наведеного, процедура отримання статусу помічника адвоката ускладнена безліччю інших бюрократичних дій, які створюють суттєві перепони на шляху до виникнення цього статусу. Ключовою проблемою, яка потім має важливий вплив на подальшу діяльність особи, є співвідношення моментів виникнення трудових правовідносин із помічником адвоката і власне отримання статусу помічника адвоката, бо на практиці ці два моменти не збігаються. Незважаючи на те, що адвокат вже прийняв особу як свого помічника, статусу ця особа набуде лише з моменту отримання посвідчення помічника адвоката.

Так, пункт 1.3.3 Положення [4] встановлює, що помічники адвоката працюють на підставі трудового договору (контракту), укладеного з адвокатом, адвокатським бюро, адвокатським об'єднанням, $з$ додержанням вимог Закону України «Про адвокатуру та адвокатську діяльність» і законодавства України про працю. Згідно з пунктом 3.2 . Положення [4] адвокат, адвокатське бюро чи адвокатське об'єднання, які уклали трудовий договір 3 помічником адвоката (заявник), звертаються із заявою до ради адвокатів регіону про видачу посвідчення помічника адвоката та внесення відомостей про помічника адвоката до СРАУ. Рада адвокатів регіону вносить дані про помічника адвоката до СРАУ відповідно до Порядку ведення СРАУ, затвердженого Радою адвокатів України, та в 30 -ти денний строк із дня надходження заяви про внесення даних про помічника адвоката до СРАУ видає посвідчення помічника адвоката, яке згідно з пунктами 4.7 та 4.12 Положення [4] підтверджує його особу та повноваження. 
Приписами пункту 8.4 Положення [4] встановлено, що до стажу роботи помічником адвоката, що дає право на звільнення від проходження стажування, враховується стаж роботи помічником адвоката, якщо помічник працював на умовах повного робочого тижня, а роботодавцем за таку особу до державного бюджету України сплачувався єдиний соціальний внесок у встановленому законом порядку та розмірі. Не зараховується як стаж роботи помічника адвоката, необхідний для звільнення від проходження стажування, робота особи на посаді помічника адвоката за сумісництвом та на умовах цивільно-правових договорів.

Таким чином, ні Закон України «Про адвокатуру та адвокатську діяльність», ні Положення про помічника адвоката, ні інші норми не встановлюють, що підставою для обчислення стажу роботи помічника адвоката $€$ наявність посвідчення помічника адвоката, а відповідно, і не встановлюють, що перебіг початку обчислення стажу роботи розпочинається з дати видачі посвідчення чи дати внесення даних про помічника адвоката до СРАУ. Разом із тим слід враховувати пункт 4.12 Положення [4], згідно з яким особа, яка не має посвідчення помічника адвоката встановленого зразка та дані про яку не внесено до Єдиного реєстру адвокатів України, не має статусу помічника адвоката та права виконувати пов'язані з цим статусом дії.

Враховуючи вищенаведене, обчислення стажу роботи помічником адвоката (для звільнення від проходження стажування) здійснюється відповідно до приписів законодавства України про працю починаючи з дати початку роботи, визначеної трудовим договором (наказом про прийняття на роботу) між помічником та адвокатом (адвокатським бюро чи об'єднанням), за умови дотримання вимог Положення про помічника адвоката та Порядку ведення ЄРАУ щодо строків подання до відповідної РАР установлених документів про помічника адвоката.

Отже, виникають слушні запитання щодо моменту виникнення трудових правовідносин і моменту отримання статусу помічника адвоката. Чи збігаються у часі ці два юридичних факти? Та який із цих двох фактів матиме значення для отримання у майбутньому свідоцтва на ведення адвокатської діяльності? Для з'ясування відповідей розглянемо процедуру, яка встановлена для отримання посвідчення помічника адвоката та виникнення трудових правовідносин.

Адвокат, адвокатське бюро чи адвокатське об'єднання, які уклали трудовий договір 3 помічником адвоката (заявник), звертаються із заявою до ради адвокатів регіону про видачу посвідчення помічника адвоката та внесення відомостей про помічника адвоката до СРАУ. У разі оформлення трудових відносин з адвокатом, який здійснює адвокатську діяльність індивідуально, заява подається до ради адвокатів регіону за адресою робочого місця адвоката згідно з даними СРАУ.

До заяви про внесення даних про помічника адвоката до СРАУ та видачу посвідчення помічника адвоката додаються такі документи: (1) письмова згода помічника адвоката на обробку його персональних даних і на проведення перевірки повноти та достовірності повідомлених ним відомостей, зобов'язання щодо надання необхідних для перевірки документів на запит ради адвокатів регіону; (2) нотаріально посвідчена копія документа державного зразка, що підтверджує здобуття помічником адвоката повної вищої освіти за такими спеціальностями: «Правознавство», «Правоохоронна діяльність», «Міжнародне право»; (3) документ встановленої форми (довідка, витяг) про відсутність у такої особи судимості, виданий компетентним органом; (4) довідка медичної установи про стан здоров'я помічника адвоката (медична довідка про проходження обов'язкових попереднього та періодичного психіатричних оглядів форма № 2-2/о, затверджена Наказом МОЗ України № 12 від 17.01.2002); (5) копія паспорта помічника адвоката; (6) копія реєстраційного номера облікової картки платника податків, за винятком випадків, коли особа відмовилася від отримання такого номеру через релігійні переконання; (7) копія трудової книжки із записом про прийняття на роботу особи в якості помічника адвоката із зазначенням прізвища, імені, по батькові адвоката, помічником якого така особа прийнята на роботу; (8) копія наказу про прийняття на роботу в адвокатське бюро, адвокатське об'єднання помічника адвоката із зазначенням прізвища, імені, по батькові адвоката, помічником якого така особа прийнята на роботу; (9) трудовий договір (контракт) (оригінал для огляду) та його копія; (10) автобіографія помічника адвоката; (11) 3 (три) фотографії помічника адвоката розміром 3 см на 4 см та на електронному носії; (12) копія квитанції або платіжного доручення з відміткою банківської установи про здійснення оплати за посвідчення помічника адвоката; (13) копія квитанції або платіжного доручення 3 відміткою банківської установи про сплату внеску за внесення відомостей стосовно помічника адвоката до Єдиного реєстру адвокатів України; (14) підтвердження від Вищої школи адвокатури НААУ про проходження курсу-інструктажу введення в професію помічника адвоката. 
У разі ненадання цих документів рада адвокатів регіону повідомляє заявника про необхідність усунення цих недоліків у 30 -денний строк. У разі, якщо у встановлений строк недоліки не будуть усунені, така заява разом із додатками повертається заявнику.

Посвідчення помічника адвоката видається заявнику особисто або на підставі довіреності, оформленої відповідно до закону (адвокати, які здійснюють свою діяльність індивідуально, надають нотаріально посвідчену довіреність; довіреність адвокатського бюро/адвокатського об'єднання оформлюється на бланку юридичної особи за підписом керівника та скріплюється печаткою).

Посвідчення помічника адвоката підтверджує його особу та повноваження. Особа, яка не має посвідчення помічника адвоката встановленого зразка та дані про яку не внесено до Єдиного реєстру адвокатів України, не має статусу помічника адвоката та права виконувати пов'язані з цим статусом дії.

КЗпП України чітко не визначає моменту виникнення трудових правовідносин між працівником та роботодавцем, але за загальним правилом трудові правовідносини виникають з моменту укладення трудового договору. Трудовий договір, як зазначає П. Д. Пилипенко, є двосторонньою угодою, що базується на взаємному волевиявленні двох сторін - працівника і роботодавця. Іншими словами, угода сторін як підстава для виникнення трудових правовідносин виражається назовні у формі трудового договору [5, с. 43-44].

У деяких випадках правові норми пов'язують виникнення трудових правовідносин не $з$ одним юридичним фактом, яким $\epsilon$ трудовий договір, а з декількома. Складні юридичні факти ще прийнято називати фактичними складами, тобто сумою декількох одиничних фактів, яким норми права надають юридичного значення лише за наявності їх в усій сукупності, оскільки саме в такому своєму комплексі вони породжують, змінюють чи припиняють правовідносини. Приміром, фактичний склад має при призначенні на посаду державних службовців, оскільки виникненню трудових правовідносин передує проходження конкурсу.

У ситуації з помічниками адвокатів на практиці все зводиться до того, що адвокат уклав трудовий договір з особою, надіслав повідомлення до територіальних органів Державної фіскальної служби України (за місцем обліку як платника єдиного внеску на загальнообов'язкове державне соціальне страхування) про прийняття помічника адвоката на роботу до початку роботи за укладеним трудовим договором, тобто де-юре між адвокатом та помічним вже виникли трудові правовідносини, але, незважаючи на це, помічник адвоката де-факто залишається безправною особою, позаяк не має посвідчення помічника адвоката, яке видається за підписом голови ради адвокатів регіону. Для того, щоб помічник адвоката отримав це свідоцтво, він має виконати вищенаведені дії. Іншими словами, особа вже прийнята на роботу помічником адвоката, але оскільки посвідчення ця особа не має, то фактично не може виконувати доручення свого роботодавця. I тому цей строк (перебування у трудових правовідносинах, але без посвідчення помічника адвоката) не зарахується до стажу роботи, який надалі потрібен для отримання посвідчення адвоката.

Описана ситуація, яка має місце на практиці, щодо прийняття на роботу помічника адвоката видається дуже складною та дивною. Чому адвокат як самозайнята особа повинен фактично чекати схвалення радою адвокатів регіону кандидатури вже прийнятої на роботу особи як помічника адвоката? Адже це особиста справа адвоката як роботодавця, кого прийняти на роботу. Крім цього навряд чи адвокат прийме на роботу особу некваліфіковану, адже саме адвокат відповідатиме за дії свого помічника.

У зв'язку з цим ми переконані, що Рада адвокатів регіону має лише вносити відомості про помічника адвоката до реєстру, тобто дії Ради адвокатів мають бути зведені лише до формального, технічного аспекту, зокрема, на нашу думку, цю процедуру доцільно звести до декількох дій: (1) адвокат повідомляє, що прийняв на роботу помічника; (2) надає копію квитанції або платіжного доручення 3 відміткою банківської установи про здійснення оплати за посвідчення помічника адвоката та копію квитанції або платіжного доручення з відміткою банківської установи про сплату внеску за внесення відомостей стосовно помічника адвоката до Єдиного реєстру адвокатів України; (3) помічник адвоката надає копію паспорта; копію реєстраційного номера облікової картки платника податків; копію трудового договору, трудової книжки, копію наказу про прийняття на роботу; нотаріально посвідчену копію документа державного зразка, що підтверджує здобуття помічником адвоката повної вищої освіти за такими спеціальностями: «Правознавство», «Правоохоронна діяльність», «Міжнародне право»; документ встановленої форми (довідка, витяг) про відсутність у такої особи судимості, виданий компетентним органом, а також медичну довідку про проходження обов'язкових попереднього та періодичного психіатричних оглядів. 
На підставі цих документів Рада адвокатів зобов’язана внести дані до реєстру про помічника адвоката та видати посвідчення помічника адвоката. Вважаємо, що Рада адвокатів має бути позбавлена права відмовляти у виданні посвідчення помічника адвоката на підставі усіх наданих належним чином оформлених вищенаведених документів, позаяк в іншій ситуації буде не зрозуміло, хто приймає на роботу помічника адвоката - Рада адвокатів регіону чи все ж таки адвокат. Окрім цього, стаж помічника адвоката має рахуватися $з$ моменту виникнення трудових правовідносин між адвокатом та його помічником. Вважаємо, що датою отримання свідоцтва про помічника адвоката має бути саме дата виникнення трудових правовідносин із ним, позаяк уже 3 цього моменту особа починає безпосереднє виконання своєї трудової функції. Внесення даних до реєстру та виготовлення посвідчення помічника адвоката повинні стати лише формальним підтвердженням того, що певний адвокат має власного помічника.

Вимагати від помічника підвищувати свій рівень кваліфікації може лише адвокат як роботодавець. Натомість у п. 3.5.14 Положення [4] обов'язковим документом для отримання посвідчення адвоката є підтвердження від Вищої школи адвокатури НААУ про проходження курсу-інструктажу введення в професію помічника адвоката. Крім цього, у п. 8.3 Положення [4] визначено, що помічник адвоката зобов'язаний постійно підвищувати свій професійний рівень та кваліфікацію, зокрема щорічно в обов'язковому порядку прослухати будь-які (на власний вибір) навчальні курси (навчальні продукти) Вищої школи адвокатури НААУ загальною тривалістю не менше ніж 10 годин (п. 8.3.3) [4]. Вважаємо, що вимога про проходження курсу-інструктажу введення в професію помічника адвоката Вищої школи адвокатури НААУ для особи, яка має повну вищу юридичну освіту, порушує принцип доступу до професії, адже підтвердженням професійного рівня особи є диплом про повну вищу освіту, позаяк особа, яка має такий рівень підготовки, володіє необхідним «багажем» знань для виконання тих завдань та доручень, які надаватиме адвокат.

\section{Висновки}

Таким чином, процедура отримання статусу помічника адвоката занадто ускладнена, а тому потребує суттєвого спрощення та переформатування. Вважаємо, що стаж помічника адвоката має рахуватися 3 моменту виникнення трудових правовідносин між адвокатом та його помічником, а датою отримання свідоцтва про помічника адвоката має бути саме дата виникнення трудових правовідносин із ним, позаяк уже з цього моменту особа починає безпосереднє виконання своєї трудової функції. Внесення даних до реєстру та виготовлення посвідчення помічника адвоката повинні стати лише формальним підтвердженням того, що певний адвокат має власного помічника.

Вимога про проходження курсу-інструктажу введення в професію помічника адвоката Вищої школи адвокатури НААУ для особи, яка має повну вищу юридичну освіту, порушує принцип доступу до професії, адже підтвердженням професійного рівня особи $\epsilon$ диплом про повну вищу освіту, позаяк особа, яка має такий рівень підготовки, має необхідні знання для виконання тих завдань та доручень, які надаватиме адвокат.

\section{Список використаних джерел:}

1. Яковлєв О. А. Проблемні питання трудового права у Законі України «Про адвокатуру і адвокатську діяльність». Вісник Харківського нащіонального університету імені В. Н. Каразіна. Серія «Право». 2013. Вип. № 14. С. 142-145.

2. Про адвокатуру та адвокатську діяльність : Закон України від 05.07.2012 № 5076-VI. Відомості Верховної Ради Украӥни. 2013. № 27. Ст. 282.

3. Кодекс законів про працю України : Закон України від 10.12.1971 № 322-VIII. Вiдомості Верховної Ради УРСР. 1971. Дод. до № 50.

4. Положення про помічника адвоката : затверджене рішенням Ради адвокатів України від 25.09.2015 № 113. URL: https://unba.org.ua/assets/ uploads/legislation/pologennya/2018-09-08polozhennya-140_5bbc6f2dba29f.pdf (дата звернення: 03.08.2019).

5. Пилипенко П. Д. Підстави виникнення індивідуальних трудових правовідносин : монографія. Київ : Т-во «Знання», КОО, 2003. 146 с.

The article addresses the problematic issues that arise when having an employment relationship with a lawyer's assistant. The author touches on important aspects concerning the emergence of a legal employment relationship and obtaining the status of an assistant lawyer. In particular, the author asks questions and answers regarding the moment when the employment relationship arises and when he / she becomes a lawer's assistant. The author finds out which of these two facts will be relevant for obtaining a future attorney's certificate, from which point in time the attorney's assistant's experience begins to be calculated.

The author found that a significant problem for a lawyer's assistant to realize his or her job function and to obtain work experience as a lawyer's assistant is that in practice the following situation occurs: a person is already hired as a lawyer's assistant, but since this person does not have a certificate, in fact can fulfill the 
orders of his employer. That is why this term (stay in employment relationship, but without the certificate of a lawyer's assistant) is not counted towards the length of service, which is later required for obtaining a lawyer's certificate.

The author concluded that the procedure for obtaining the status of Assistant Counsel is too complicated and therefore requires considerable simplification and reformatting. It is argued that the length of a lawyer's assistant should be counted from the moment of the employment relationship between the laweyer and his assistant, and the date of receipt of the certificate of the assistant lawyer should be the date of the employment relationship with him, since from that moment the person begins to perform his / her job directly. Entering the register and producing a lazoyer's assistant certificate - should only be a formal confirmation that a lawyer has his or her own assistant. The Council of Advocates of the region only needs to enter information about the assistant lawyer into the register, that is, the actions of the Council of Advocates should be reduced to a formal, technical aspect only. It is argued that the requirement to enter the profession of entering the profession of Assistant Lawyer of the Higher School of Law of NAAU for a person with a full higher legal education violates the principle of access to the profession, since the professional qualification of the person is a diploma of higher education, since has the level of training he has the necessary knowledge to carry out the tasks and assignments that the lawyer will provide.

Key words: lawyer's assistant, labor relations, lawyer's activity, certificate of assistant's lawyer, status of assistant's lawyer, experience of assistant's lawyer. 